\title{
Percutaneous endoscopic necrosectomy using an automated rotor resection device in severe necrotizing pancreatitis
}

Endoscopic transgastric necrosectomy is a first-line treatment for infected pancreatic necroses following acute pancreatitis [1, 2]. However, the accessibility of walled-off necrotic collections in the paracolic gutter often remains challenging. EndoRotor (Interscope Medical, Inc., Worcester, Massachusetts, USA) is a novel device for effective necrosectomy [2-4]. This is the first published case using it in a percutaneous setting. We report the case of a 34-year-old man transferred to our hospital intensive care unit (ICU) following severe necrotizing pancreatitis. Complications such as sepsis, acute kidney failure requiring dialysis, and abdominal compartment resulted in a prolonged stay at our ICU.

Large, infected, walled-off necrotic collections remained in the left and right retroperitoneum. Owing to their location, the collections were not suitable for transgastric interventions and therefore percutaneous drainage was used as a primary therapy ( $\mathbf{F i g . 1}$ ).

At 3 months of percutaneous drainage and intravenous antibiotic therapy without resolution of the necrotic tissue in the left retroperitoneum, percutaneous endoscopic necrosectomy was performed twice using the novel EndoRotor resection device ( $>$ Video $\mathbf{1})$. Percutaneous dilation was performed from 14 to $18 \mathrm{~mm}$ to allow insertion of the flexible endoscope into the retroperitoneal cavity. Necrosectomy was then carried out with the flexible EndoRotor device by using high suction $(750 \mathrm{mmHg}$ ) and low cutting speed (1000 rpm).

Except for the persistence of a cutaneous fistula for less than a week after intervention, no adverse events were observed. The patient's condition improved, and he was discharged 7 days after the initial necrosectomy.

Endoscopy_UCTN_Code_TTT_1AO_2AN

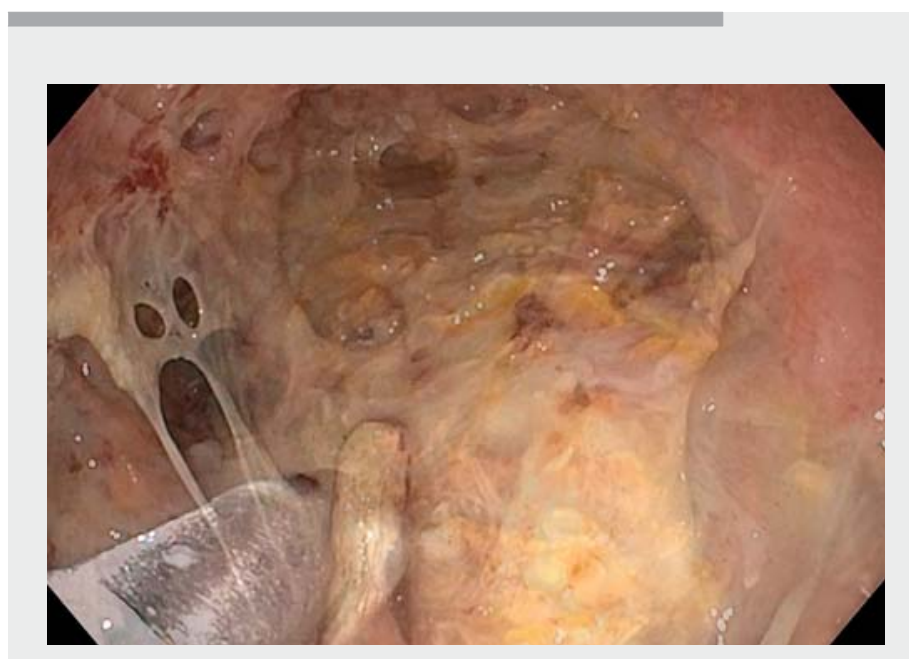

Video 1 Percutaneous dilation and subsequent endoscopic necrosectomy was performed using the EndoRotor device (Interscope Medical, Inc., Worcester, Massachusetts, USA).

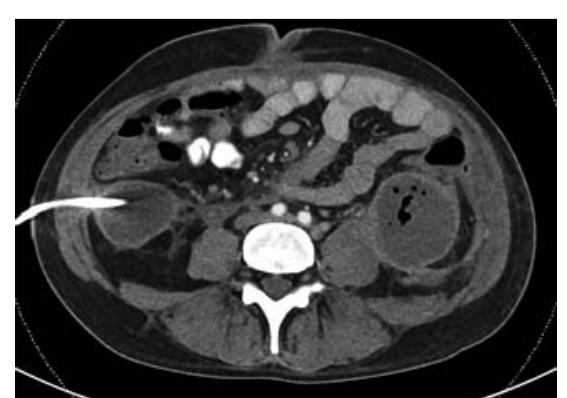

Fig. 1 Computed tomography showed necrotic collections in the left and right lower retroperitoneal area. The percutaneous drainage tube can be seen on the right side of the patient.

\section{Competing interests}

The authors declare that they have no conflict of interest.
The authors

Sophie Zeuner, Fabian Finkelmeier, Oliver Waidmann, Joerg Bojunga, Stefan Zeuzem, Mireen Friedrich-Rust, Mate Knabe Department of Internal Medicine 1, University Hospital Frankfurt, Frankfurt, Germany

Corresponding author

Mate Knabe, MD

Medizinische Klinik I, Univrsitäsklinikum

Frankfurt, Theodor-Stern-Kai 7,

636069 Frankfurt, Germany

Mate.Knabe@kgu.de 


\section{References}

[1] Working Group IAP/APA Acute Pancreatitis Guidelines. IAP/APA evidence-based guidelines for the management of acute pancreatitis. Pancreatology 2013; 13: e1-e15

[2] Arvanitakis M, Dumonceau JM, Albert J et al. Endoscopic management of acute necrotizing pancreatitis: European Society of Gastrointestinal Endoscopy (ESGE) evidencebased multidisciplinary guidelines. Endoscopy 2018; 50: 524-546

[3] van der Wiel SE, Poley JW, Grubben M et al. The EndoRotor, a novel tool for the endoscopic management of pancreatic necrosis. Endoscopy 2018; 50: E240-E241
[4] Rizzatti G, Rimbas M, Impagnatiello M et al. Endorotor-based endoscopic necrosectomy as a rescue or primary treatment of complicated walled-off pancreatic necrosis. A case series. J Gastrointestin Liver Dis 2020; 29: 681-684

\section{Bibliography}

Endoscopy 2022; 54: E362-E363

DOI 10.1055/a-1540-6191

ISSN 0013-726X

published online 9.8.2021

(c) 2021. Thieme. All rights reserved.

Georg Thieme Verlag KG, Rüdigerstraße 14,

70469 Stuttgart, Germany

\section{ENDOSCOPY E-VIDEOS}

https://eref.thieme.de/e-videos

口回 Endoscopy E-Videos is an

open access online section, 回释: reporting on interesting cases and new techniques in gastroenterological endoscopy. All papers include a high quality video and all contributions are freely accessible online. Processing charges apply (currently EUR 375), discounts and wavers acc. to HINARI are available.

This section has its own submission website at

https://mc.manuscriptcentral.com/e-videos 